\title{
Biomonitoring of Heavy Metal Air Pollution in Warsaw Using Two Moss Species Pleurozium schreberi and Sphagnum palustre
}

\author{
Biomonitoring zanieczyszczenia powietrza metalami ciężkimi w Warszawie \\ z wykorzystaniem dwóch gatunków mchów Pleurozium schreberi i Sphagnum palustre
}

\author{
Krassimira Ilieva-Makulec ${ }^{1}$, Paweł Dariusz Plichta $^{2}$, Maciej Sierakowski ${ }^{1}$ \\ ${ }^{1}$ Institute of Biological Sciences, Cardinal Stefan Wyszyński University in Warsaw, Poland \\ ${ }^{2}$ Centre for Ecology and Ecophilosophy, Cardinal Stefan Wyszyński University in Warsaw, Poland \\ ORCID KI-M https://orcid.org/0000-0002-7570-3822; MS https://orcid.org/0000-0003-3770-2762•k.makulec@uksw.edu.pl \\ Received: 13 Sep, 2021; Revised: 20 Oct, 2021; Accepted: 5 Nov, 2021
}

\begin{abstract}
The aim of the study was to assess air pollution with heavy metals in Warsaw, on the basis of the concentrations of selected elements in moss samples. The active biomonitoring method (moss-bag technique) was applied using two moss species Pleurozium schreberi and Sphagnum palustre. Moss samples were collected in the Kampinos National Park, and the prepared moss bags were distributed and exposed on seven sites in Warsaw. The analysis of metals accumulated in mosses was performed twice in 2020, after two (August-September) and four months (August-November) of exposure. The concentrations of seven heavy metals $(\mathrm{Cr}, \mathrm{Cu}, \mathrm{Pb}, \mathrm{Ni}, \mathrm{Fe}, \mathrm{Cd}$ and $\mathrm{Zn})$ in the mosses were determined, using an Inductively Coupled Plasma Optical Emission Spectrometer (ICP OES). Our results showed a clear dependence of heavy metal accumulation in the mosses on the location of the exposition site and the exposure period. Both species of mosses were found to accumulate the most metals in the vicinity of pollutant emitters, such as the ArcelorMittal Warsaw smelter, exit roads or roads in the city with heavy traffic, petrol stations, or construction works. After 4 months of exposure, in both moss species, the highest increases in the concentrations were found for four elements: $\mathrm{Cr}, \mathrm{Pb}, \mathrm{Ni}$ and $\mathrm{Cd}$. Higher concentrations of some heavy metals in the mosses in 2020, as compared to previous studies, indicate a negative influence of progressing urbanisation on air pollution in Warsaw.
\end{abstract}

Keywords: mosses, heavy metals, air pollution, Warsaw, bioindication

Streszczenie: Celem przeprowadzonych badań była ocena zanieczyszczenia powietrza metalami ciężkimi w Warszawie na podstawie przyrostów stężeń wybranych pierwiastków w tkankach mchów. Zastosowano metodę biomonitoringu aktywnego (moss-bag technique) wykorzystując dwa gatunki mchów Pleurozium schreberi (rokietnik pospolity) oraz Sphagnum palustre (torfowiec błotny). Próbki mchów pobrano w Kampinoskim Parku Narodowym, a przygotowane z nich pakieciki wyeksponowano na siedmiu stanowiskach na terenie Warszawy. Analizę metali zakumulowanych w mchach wykonano dwukrotnie w 2020 roku, po dwóch (sierpień-wrzesień) i czterech miesiącach (sierpień-listopad) ekspozycji. Zawartość metali ciężkich ( $\mathrm{Cr}, \mathrm{Cu}, \mathrm{Pb}, \mathrm{Ni}, \mathrm{Fe}, \mathrm{Cd}$ and $\mathrm{Zn}$ ) w mchach oznaczono stosując technikę atomowej spektrometrii emisyjnej ze wzbudzeniem w plazmie indukowanej (ICP OES). Stwierdzono wyraźną zależność kumulacji metali ciężkich w mchach od lokalizacji stanowiska oraz terminu ekspozycji. Oba gatunki mchów kumulowały najwięcej metali w pobliżu emitorów zanieczyszczeń takich jak: huta ArcelorMittal Warszawa, drogi wylotowe lub drogi w mieście o dużym natężeniu ruchu, stacje paliw czy prace budowlane. Po 4 miesiącach ekspozycji, u obu gatunków mchów, największe przyrosty stężeń stwierdzono dla czterech pierwiastków: Cr, Pb, Ni i Cd. Wyższe koncentracje niektórych metali ciężkich w mchach w 2020 
roku, w porównaniu z wcześniejszymi badaniami, wskazują na negatywny wpływ postępującej urbanizacji na zanieczyszczenie powietrza w Warszawie.

Słowa kluczowe: mchy, metale ciężkie, zanieczyszczenie powietrza, Warszawa, bioindykacja

\section{Introduction}

The quality of air in urban agglomerations is a serious concern all over the world. The concentrations of harmful substances (including heavy metals) present in the air, often exceed the acceptable standards (Rozbicka and Michalak 2015; Kostrz and Satora 2017, 89-93).

In the Warsaw agglomeration, the main source of air pollution with heavy metals is anthropogenic emission, which comes from industrial activity (point emission), as well as municipal and household sector (surface emission), and transport (linear emission). Major sources of air pollution in Warsaw are fuel combustion in heat and power plants (Żerań and Siekierki), heating plants (Kawęczyn, Wola) or households, as well as road transport and related exhaust fumes and pollutants from road surface abrasion, tyres, or brake pads. Another source of air emissions in Warsaw is the metallurgical industry, namely the steelworks (ArcelorMittal), located in the northern part of the city (Baczewska et al. 2016; GIOŚ 2020, 19).

Assessment of atmospheric air pollution with heavy metals such as $\mathrm{Pb}, \mathrm{Cd}$, or $\mathrm{Ni}$ in Poland is determined on the basis of their content in PM1o particles. The reports of the Chief Inspectorate for Environmental Protection, including those for 2020 , show that the average annual levels of these elements in Warsaw did not exceed permissible threshold standards (GIOŚ 2020, 70-93; 2021, 65-86). However, this does not mean that in some months, or even on particular days, they were not exceeded.

In the assessment of air pollution in urban areas, biomonitoring methods alone, or in combination with chemical analyses, have been increasingly applied in recent years. Bioindicators such as vascular plants, mosses, and lichens, have been used in many studies for assessing the level of air pollution with heavy metals (Feder and Manning 1978; Zimny 2006; Rajfur et al. 2010).

Mosses are characterised by high accumulation capacity in relation to metal ions. Due to the fact that they have no epidermis or cuticle, they can absorb, through their leaf blades, large amounts of trace elements from precipitation and from atmospheric dust. The content of metals, accumulated in mosses, correlates well with their levels in ambient air (Goodman and Roberts 1971; Zechmeister et al. 2003; Dmuchowski and Bytnerowicz 2009). Therefore, mosses are the most commonly used biomonitors of heavy metal air pollution (Grodzińska 1978, Grodzińska and Szarek 1995, 33-35; Berg and Steinnes; 1997 Grodzińska in. 1999; Wójciak 2007; Dmuchowski and Bytnerowicz 2009; Chen et al. 2010; Traczewska 2011, 98-100, 138-139; Malzahn and Wójcik 2012; Kłos 2017; Hu et al. 2018).

In urban agglomerations (where mosses are absent or rare, near transport routes or industrial plants) mosses are used in the socalled active biomonitoring. This is based on transplanting mosses (moss-bag technique) from a reference area (with a relatively low level of pollution) to the monitored area. It was developed by Goodman and Roberts (1971) to assess heavy metal contamination of ambient air in Wales. The moss-bag technique has been widely used throughout the world (Goodman and Roberts 1971; Roberts 1972; Chmielewski et al. 1993; Tavares and Vasconcelos 1996; Dmuchowski, et al. 2001, Dmuchowski and Bytnerowicz 2009, Baczewska, et al. 2016).

The aim of the present study was to assess atmospheric air pollution with heavy metals in Warsaw in 2020, using the accumulation capacity of two moss species Sphagnum 
palustre and Pleurozium schreberi, exposed for four months at different locations in the city (Fig. 1). Previously, similar studies in Warsaw were carried out by Dmuchowski and Bytnerowicz (2009) and Baczewska et al. (2016).

Our research hypotheses assumed: I) site-depending differences in the heavy metal content in mosses II) the highest accumulation of metals at the site closest to the emission source, III) a significant effect of exposure term on the level of heavy metal accumulation in mosses, IV) no significant differences in accumulation capacity between the two moss species.

\section{Description of the moss exposition sites}

Seven sites located in different areas of Warsaw were chosen for the moss bags exposition (Fig. 1, Tab. 1).

Site no. 1 (UKSW) was located on the campus of Cardinal Stefan Wyszynski University, at 1/3 Wóycickiego Str. (Fig. 1). In the near vicinity, low-rise residential buildings dominate. Approximately 60 metres from the place where moss samples were exposed, from March 2020, a new building of the Medical Faculty is under construction. To the north of the site, at a distance of about $350 \mathrm{~m}$ truck road No. 7 (DK7) runs, which is an important road for travel in and out of the city. The site was located about $1.8 \mathrm{~km}$ from steelworks ArcelorMittal Warszawa (formerly Huta Warszawa) and 5.4 km from Żerań Heat Power Station (coalfired heat power station).

Site no. 2 (DK7) was located in the area of the Lotos petrol station, at the corner of Wóycicki Str. with the DK 7 (Fig. 1 and Photo. 1). The distance from this exposition site was about 10 metres to DK no. 7 , about $2 \mathrm{~km}$ from ArcelorMittal Warszawa in a southern direction, and $5.4 \mathrm{~km}$ from Żerań Combined Heat and Power Plant in an eastern direction.

Site no. 3 (IMGW) was located within the area of the Institute of Meteorology and Water Management - National Research Institute (Fig. 1). A tramway track runs approx.
$20 \mathrm{~m}$. from the site. The monitored site was located about $2.5 \mathrm{~km}$ from Żerań Combined Heat and Power Station, about $1.5 \mathrm{~km}$ from $\mathrm{DK}_{7}$, and about $1 \mathrm{~km}$ from expressway $\mathrm{S} 8$.

Site no. 4 (Centrum) was located in the very centre of Warsaw (Fig. 1). It is shielded by tall tenement houses, and in its vicinity, there are very busy streets with car and tram traffic. There is no greenery in the area, except for the monitored site a small garden with a few shrubs.

Site no. 5 (Siekierki) was located in the area of Family Allotment Gardens, "Wilanów", about $1 \mathrm{~km}$ from the Siekierki Combined Heat and Power (CHP) Station (Fig. 1). At a distance of about 50 m., there is a railroad track leading to the CHP plant. The site was surrounded by allotments with many trees and bushes, as well as abandoned fields and meadows.

Site no. 6 (Ząbki) was located within the area of Family Allotment Gardens, "Kolejarz", on the border between Warsaw and the town, Ząbki, where low-rise single-family buildings dominate (Fig. 1). The site was located at a distance of about $2 \mathrm{~km}$ to the expressway, S8; at a distance of about $1 \mathrm{~km}$ from a large busy street and about $0.5 \mathrm{~km}$ from the railway line.

Site no. 7 (Wawer) is located within the area of "Śnieguliczka" Family Allotment Gardens at a distance of about 200-300 metres from Trakt Lubelski and Wał Miedzeszyński routes (important exit routes from Warsaw) (Fig. 1). Siekierki CHP Plant is located about $4 \mathrm{~km}$ from this site.

\section{Materials and methods}

\subsection{Moss sampling}

The samples of two moss species were used in the study: Schreber's big red stem moss Pleurozium schreberi (Brid.) Mitt. (Photo. 2) and blunt-leaved bogmoss Sphagnum palustre L. (Photo. 3). Moss samples were collected from the peat bog "Długie Bagno", the Roman Kobendza Sieraków Strict Protection Area in Kampinoski National Park. Only above-ground green parts of both moss species were collected. 


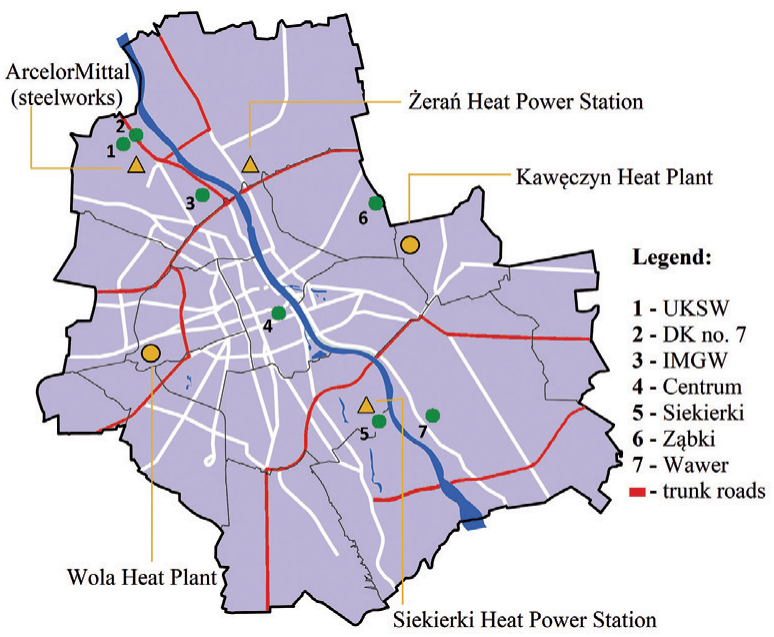

Figure 1. A map of Warsaw showing the seven monitored sites and main sources of air pollution in the city

Source: https://upload.wikimedia.org/wikipedia/commons/7/74/Warszawa_outline_with_districts_v4.svg, modified.)

Table 1. Location of the exposition sites

\begin{tabular}{ccc}
\hline No. & Site & GPS coordinates \\
\hline 1 & UKSW & $52^{\circ} 18^{\prime} 40.58^{\prime \prime} \mathrm{N} ; 20^{\circ} 55^{\prime} 5.28^{\prime \prime} \mathrm{E}$ \\
\hline 2 & DK nr 7 & $52^{\circ} 18^{\prime} 48.9^{\prime \prime} \mathrm{N} ; 20^{\circ} 55^{\prime} 17.4^{\prime \prime} \mathrm{E}$ \\
\hline 3 & IMGW & $52^{\circ} 16^{\prime} 51.57^{\prime \prime} \mathrm{N} ; 20^{\circ} 57^{\prime} 32.67^{\prime \prime} \mathrm{E}$ \\
\hline 4 & Centrum & $52^{\circ} 13^{\prime} 54.62^{\prime \prime} \mathrm{N} ; 21^{\circ} 0^{\prime} 55.16^{\prime \prime} \mathrm{E}$ \\
\hline 5 & Siekierki & $52^{\circ} 10^{\prime} 50.95^{\prime \prime} \mathrm{N} ; 21^{\circ} 5^{\prime} 37.39^{\prime \prime} \mathrm{E}$ \\
\hline 6 & Ząbki & $52^{\circ} 17^{\prime} 26.6^{\prime \prime} \mathrm{N} ; 21^{\circ} 5^{\prime} 38.09^{\prime \prime} \mathrm{E}$ \\
\hline 7 & Wawer & $52^{\circ} 10^{\prime} 43.91^{\prime \prime} \mathrm{N} ; 21^{\circ} 8^{\prime} 49.32^{\prime \prime} \mathrm{E}$ \\
\hline
\end{tabular}

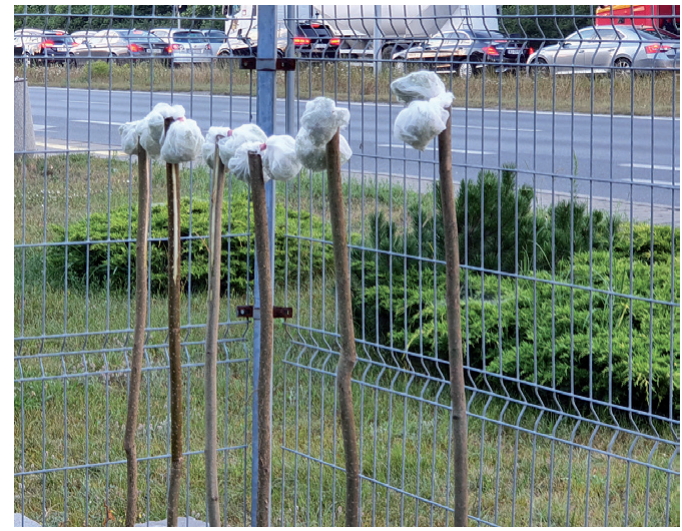

Photograph 1. A view of the exposition site DK7

\subsection{Moss bag preparation and exposure}

The moss samples were prepared for the exposition, according to the moss biomonitoring bag technique (Chmielewski et al. 1993, 181-185). It involved: the removal of organic and mineral impurities (plant fragments and soil); air drying the mosses to a constant weight; weighing the samples; transfer and temporary exposure of the bags at the monitored sites, picking up the samples and transporting them to the laboratory for chemical analyses.

In this study, 0.5 grams of cleaned, dried mosses were weighed and placed in a bag made of cotton gauze with a mesh size of 0.5 $\mathrm{mm}$. A total of 84 dried packets were prepared, 42 of each moss species.

The transfer and setup of moss bags at the exposition sites was conducted between July 27 and 31, 2020. At each site, 6 packets of each moss species were attached to wooden stakes at a height of 1.21.3 metres from the ground (Photo. 1). One half of the packets was picked at the end 


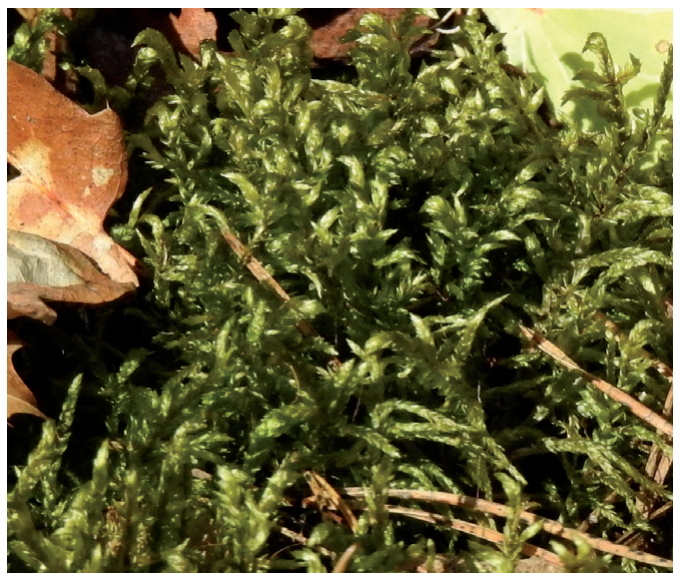

Photograph 2. Schreber's big red stem moss Pleurozium schreberi

of September (after 2 months of exposure), while the other half was picked at the end of November - after 4 months of exposure.

\subsection{Chemical analyses}

Following the exposure, twice after 2 and 4 months, the moss bags were transported to the laboratory, where moss samples were removed from the bags, and dried in the oven at $60^{\circ} \mathrm{C}$ to a constant weight. The ground samples were digested in a solution $\mathrm{HClO}_{4}: \mathrm{HNO}_{3}=1: 5$ (65\% nitric acid and $70 \%$ perchloric acid) in closed teflon containers in the microwave digestion system (Multiwave 3,00o Anton-Paar). The microwave system was operated for 90 minutes at an initial power of $850 \mathrm{~W}$, and at 400 W, when the pressure reached the 60 bar. The process temperature was $220^{\circ} \mathrm{C}$ and the reaction vessel pressure was 60 bar. Prepared solutions were transferred to volumetric flasks and diluted with deionized water (Milli-Q purity from Merck) to a final volume of $100 \mathrm{ml}$.

The concentrations of seven heavy metals $(\mathrm{Cd}, \mathrm{Cr}, \mathrm{Cu}, \mathrm{Fe}, \mathrm{Ni}, \mathrm{Pb}, \mathrm{Zn})$, accumulated in the mosses, were determined by Inductively Coupled Plasma Optical Emission Spectrometer ICP OES (ICPE-9820, Shimadzu). The operating parameters of the emission spectrometer were as follows: generator frequency $-27.12 \mathrm{MHz}$, generator

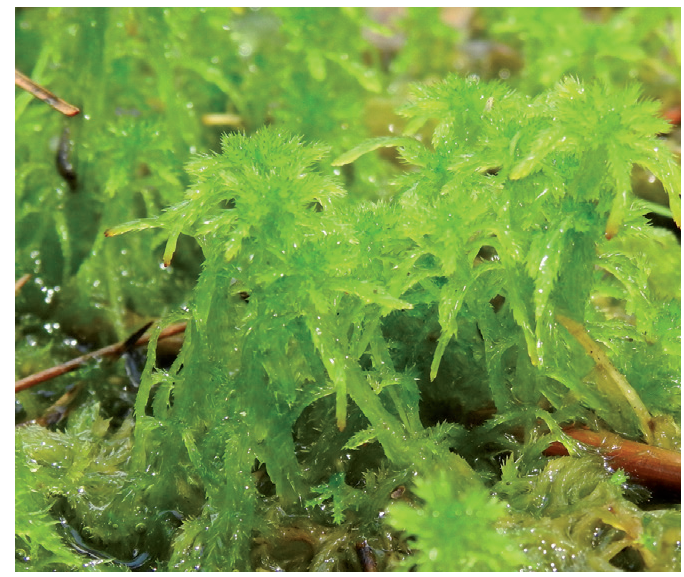

Photograph 3. Blunt-leaved bogmoss Sphagnum palustre

power $-1.20 \mathrm{~kW}$, total argon flow (99.998\% purity) $-10.00 \mathrm{~L} / \mathrm{min}$, carrier argon flow $0.70 \mathrm{~L} / \mathrm{min}$, auxiliary argon flow $-0.60 \mathrm{~L} /$ min, exposure time - $30 \mathrm{~s}$, number of exposures per trial -3 , system purge time $-30 \mathrm{~s}$, peristaltic pump speed - 20-60 rpm.

The accumulation of each heavy metal in the moss samples was calculated according to the equation:

$$
M A=\frac{100}{m} \times(c 1-c 0)
$$

where:

$M A$ - metal accumulation;

100 - flask volume $(\mathrm{ml})$;

$m$ - mass of the test moss sample;

c1- heavy metal concentration in the tested moss sample (after exposure)

co - heavy metal concentration in the moss sample (before exposure).

All metal concentrations were calculated as $\mathrm{mg} / \mathrm{kg}$ d.w.

Additionally, the relative accumulation factors (RAF) for each metal and moss species were calculated, using the equation (Kłos 2017, 63):

$$
R A F=(c 1-c 0) / c 0 .
$$

An RAF allows a comparison of the accumulation of metals, by different moss species, avoiding the effect of the initial element concentration. 


\subsection{Statistical analysis}

An analysis of variance (ANOVA) was used to assess the effect of site location and moss species, on the content of analysed heavy metals, in each moss species. In order to determine the significant differences in the moss heavy metal concentrations between the sites and between the species, the post-hoc Tukey's honest significant difference (Tukey's HSD) test was applied at $\mathrm{p}<0.05$.

\section{Results}

\subsection{Heavy metal accumulation in mosses over a 4-month exposure}

The average concentrations of $\mathrm{Cd}, \mathrm{Cr}, \mathrm{Cu}$, $\mathrm{Fe}, \mathrm{Ni}, \mathrm{Pb}$ and $\mathrm{Zn}$ in the moss samples, after 4 months of exposure, are presented in figure 2. As can be seen, the concentrations of Cd accumulated by Sphagnum palustre ranged from 0.87 at site 6 , to $1.18 \mathrm{mg} / \mathrm{kg}$ d.w. at site 1 (Fig. 2). Cd content in Pleurozium schreberi ranged from 0.56 at site 5 , to 0.77 at sites 1 and 4. For each moss species, no statistically significant differences in the content of this metal were found between sites ( $\mathrm{p}>0.05)$. At all sites, Cd concentration in P. schreberi was lower than in S. palustre, with significant differences between species found at sites 1, 3 and 6 ( $\mathrm{p}<0.05)$.

$\mathrm{Cr}$ accumulation after 4 months was the highest at site $1-20.04$ in $S$. palustre and $19.14 \mathrm{mg} / \mathrm{kg}$ d.m. in P. schreberi (Fig. 2). For each moss species, these values were significantly higher $(\mathrm{p}<0.05)$ than the accumulation of this metal at sites $3-7$, and for S. palustre additionally in site 2 . The lowest Cr concentration in $S$. palustre was found at site $5-0.97$, and in P. schreberi at site $7-0.48 \mathrm{mg} / \mathrm{kg}$ d.m. At each site, both moss species accumulated similar amounts of $\mathrm{Cr}$. Only at site 2, higher ( $\mathrm{p}>0.05$ ) Cr concentrations were found in $S$. palustre than in P. schreberi.

After 4 months of exposure, the accumulated $\mathrm{Cu}$ content in $S$. palustre ranged from 3.33 at site 7 , to $36.49 \mathrm{mg} / \mathrm{kg} \mathrm{d.m}$. at site 2, whilst in P. schreberi, it ranged from 2.89 at site 5 , to 29.38 at site 2 (Fig. 2). $\mathrm{Cu}$ concentration in both moss species at site 2, was significantly higher $(\mathrm{p}<0.05)$ than at the other sites. Significant differences in $\mathrm{Cu}$ accumulation between moss species, were found only at sites 2 and $3(\mathrm{p}<0.05)$.

The accumulated Fe content in S. palustre tissues over 4 months, ranged from 248.59 at site 7 , to $1703.81 \mathrm{mg} / \mathrm{kg} \mathrm{d.m}$. at site 2 . Fe content in P. schreberi ranged from 135.3 at site 5, to $1230.64 \mathrm{mg} / \mathrm{kg} \mathrm{d.m}$. at sites 1 and 4 . Both moss species accumulated significantly $(\mathrm{p}<$ 0.05) more iron at sites 1 and 2, compared to the other sites (Fig. 2).

At all sites, Fe concentrations in P. schreberi were lower than in S. palustre; however, significant differences $(\mathrm{p}<0.05)$ between species were found, only at sites 1 and 2 .

In both moss species, the highest $\mathrm{Ni}$ concentrations after 4 months of exposure were recorded at site $1-6.55$ in P. schreberi and $4.85 \mathrm{mg} / \mathrm{kg}$ s.m. in S. palustre (Fig. 2). However, this value was significantly higher than at the other sites only in the case of P. schreberi $(\mathrm{p}<0.05)$. For $S$. palustre, a significant difference in moss nickel content was found only between site 1 and site 7 .

During the exposition, both moss species accumulated the most $\mathrm{Pb}$ at sites 1 and 2 (Fig. 2). For each species, $\mathrm{Pb}$ contents at these two sites were significantly $(\mathrm{p}<0.05)$ higher than at the other sites. At all sites, $\mathrm{Pb}$ concentrations in S. palustre were higher than in P. schreberi, but only at site 1, was the difference between species statistically significant $(\mathrm{p}<0.05)$.

During the exposure period, the moss S. palustre accumulated the most $\mathrm{Zn}$ at site $1-436.48 \mathrm{mg} / \mathrm{kg} \mathrm{d}$.w. and this value was significantly $(\mathrm{p}<0.05)$ higher than the Zn concentrations in $S$. palustre at the other sites. At the same time, P. schreberi accumulated the most $\mathrm{Zn}$ at site $4-214.65 \mathrm{mg} / \mathrm{kg}$ d.w.. This value was significantly higher compared to the moss accumulation of this element at sites 3, 5, 7 (Fig. 2). 

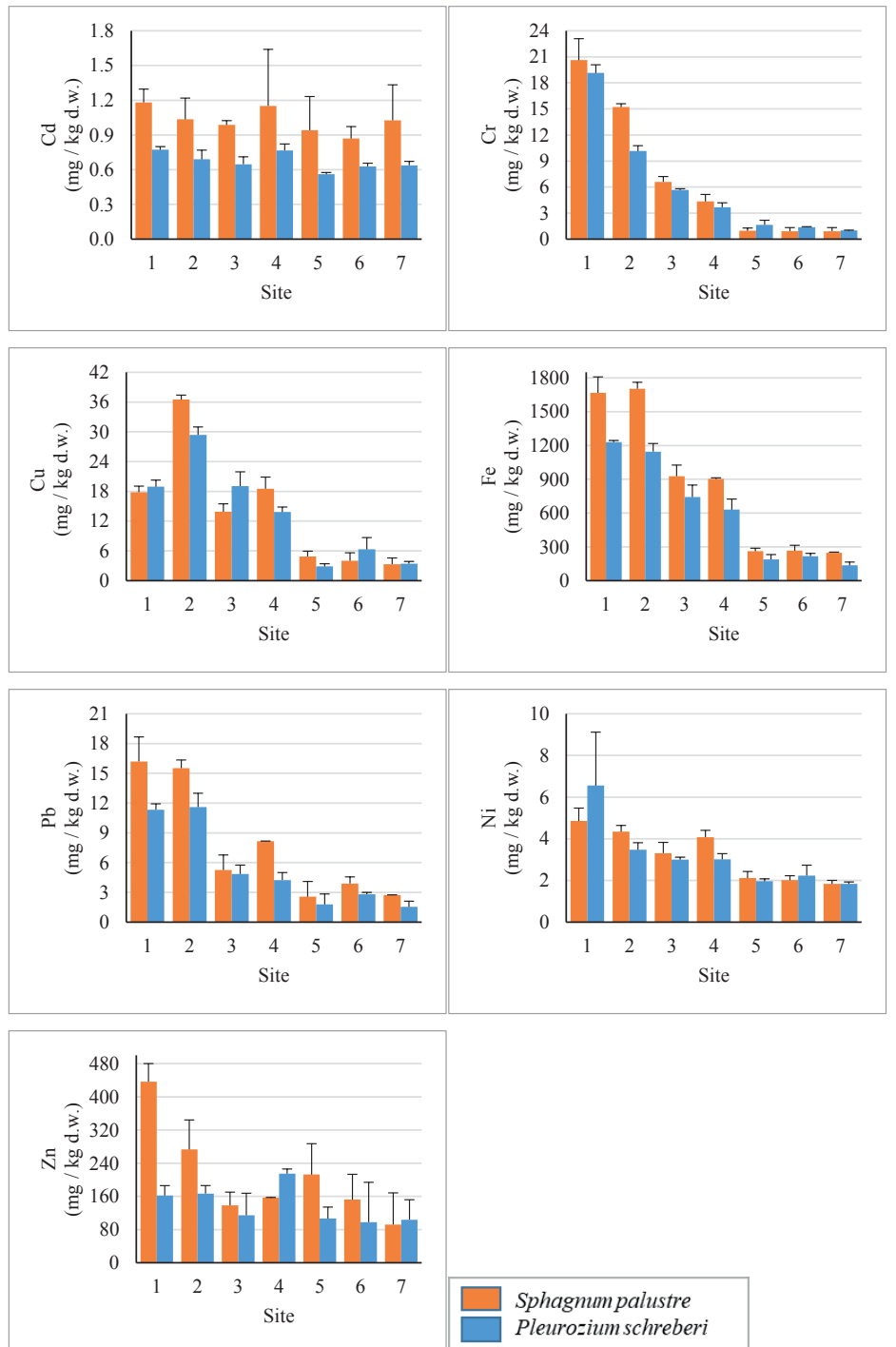

Sphagmum palustre

Pleurozium schreberi

Figure 2. Element concentration in Sphagnum palustre and Pleurozium schreberi after 4 months of moss exposure. Data presented are mean + SD values. For site names and locations, see Fig. 1 and Table 1.

\subsection{The effect of exposure term on the level of metal accumulation in mosses}

Our results showed a clear effect of the exposure period (I term - August-September, II term - October-November) on the metal accumulation, by the two moss species (Fig. 3).

At all monitored sites, both moss species accumulated significantly more $\mathrm{Cd}$ during the second exposure period, i.e. between October and November of 2020 (Fig. 3).
In the case of $S$. palustre at site 6 , and in the case of P. schreberi at sites 3, 4, and 7 the $\mathrm{Cd}$ accumulation during this period was as high as $100 \%$. For the first exposure period (August-September), the highest accumulation of $\mathrm{Cd}$ in $S$. palustre was recorded at site 1 (ca. 19\%), while in P. schreberi at site 2 (ca. 12\%).

$\mathrm{Cr}$ accumulation in $S$. palustre was also higher during the second exposure period and ranged from about $45 \%$ at sites 1 and 3 , 

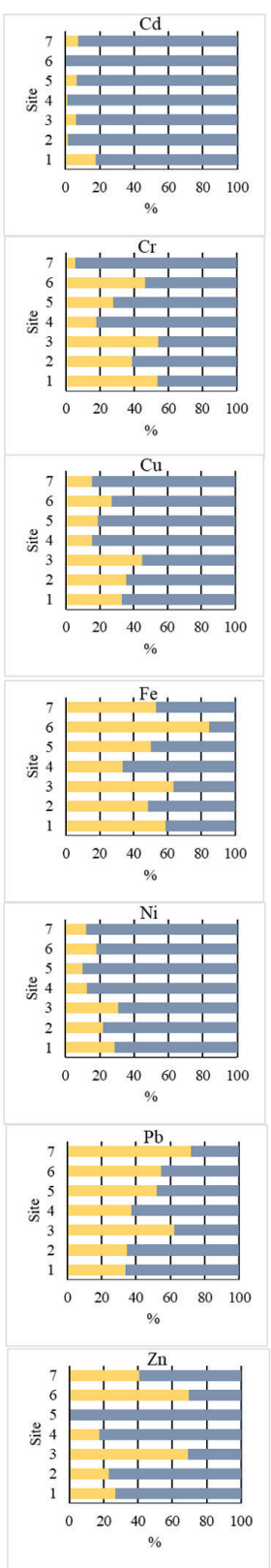
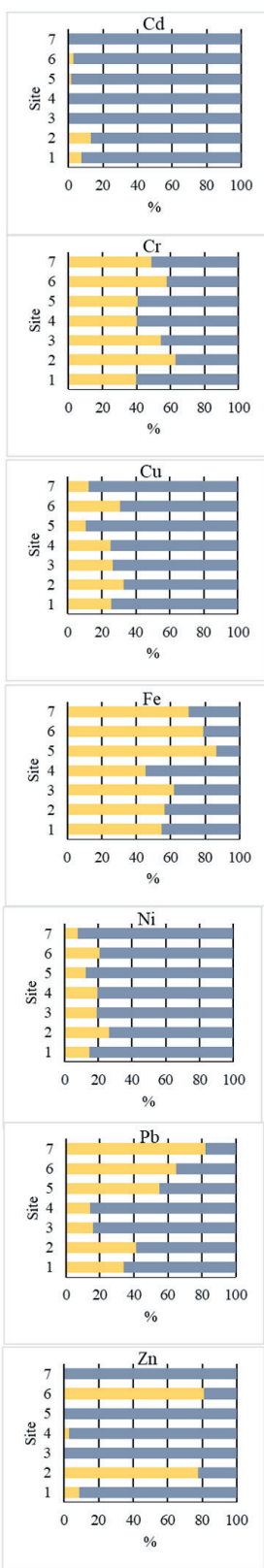

Figure 3. Comparison of metal accumulation in the mosses Sphagnum palustre (left column) and Pleurozium schreberi (right column) from two exposure periods. For names and location of the monitored sites, see Fig. 1 and Table 1.

to about $95 \%$ at site 7 . In contrast, the moss P. schreberi accumulated $\mathrm{Cr}$ at similar levels, during both exposure periods (Fig. 3).

Both moss species accumulated significantly more $\mathrm{Cu}$ in the second exposure period. The highest accumulation of this element, in this term, was recorded in $S$. palustre at site 4 (about $85 \%$ ) and in P. schreberi (about 90\%) - at site 5 (Fig. 3 ).

As can be seen on Fig. 3, at most sites, the level of Fe accumulation in S. palustre was similar in both exposure periods. Only at sites 6 and 4, were the distinct differences between the periods noticed - at 
site 6, S. palustre accumulated more Fe in the August-September period, while at site 4, it accumulated more $\mathrm{Fe}$ in the October-November period. In the case of $P$. schreberi, iron accumulation was significantly higher in the August-September period - over 50\% at all sites, except site 4 .

Nickel was the next metal that both moss species accumulated significantly more, during the second exposure period (Fig. 3).

In the case of $\mathrm{Pb}$ accumulation by studied moss species, two different trends were observed: on sites 5-7 (and additionally, on site 3 in S. palustre) the mosses accumulated more $\mathrm{Pb}$ during the $1^{\text {st }}$ period of exposure, while on the remaining sites during the $2^{\text {nd }}$ period (Fig. 3).

At most sites, both S. palustre and P. schreberi accumulated more zinc in the period from October to November, with accumulation reaching $100 \%$ at site 5 (both species), and at site 7 (P. schreberi only). Only at site 6 (both species), and at site 3 (S. palustre), and 2 (P. schreberi), more $\mathrm{Zn}$ was accumulated by mosses during the first period of exposure.

\subsection{The increments of heavy metal concentrations in mosses over the exposition}

The increase in heavy metal concentrations in mosses during the exposure, relative to their pre-exposure content was evaluated by calculating the relative accumulation factor (RAF) values. Tables 2 and 3 present the RAFs for the analysed metals in the moss species at the seven monitored sites after 4 months of exposure.

As can be seen in Table 2, the largest increases in all metal concentrations in $S$. palustre were estimated for sites 1 and/ or 2. Moreover, while at the first two sites, the greatest increases were noted for $\mathrm{Cr}$, followed by $\mathrm{Pb}$ and $\mathrm{Ni}$, and at sites $3-7$, this order was as follows: $\mathrm{Cd}>\mathrm{Ni}>\mathrm{Pb}$.

The concentration increments of all the analysed metals in the P. schreberi after 4 months of exposure, were also highest at site 1 and/or 2 (Table 3 ). The order of metals, according to their increase at sites 1 and 2, was as follows $\mathrm{Cr}>\mathrm{Ni}>\mathrm{Cd}>\mathrm{Pb}$.
The increments in metal concentrations in P. schreberi at the remaining sites, can be ranked in descending order: $\mathrm{Ni}>\mathrm{Cd}>\mathrm{Cr}$ $\geq \mathrm{Zn}$.

The RAF values indicate some differences in the accumulation capacities of the two moss species for the same metal. At almost all sites, S. palustre showed slightly higher accumulation capacities towards $\mathrm{Cd}, \mathrm{Cu}$, and Fe, whilst $P$. schreberi edged towards $\mathrm{Cr}$. As can be seen from tables 2 and 3, significant differences between the two moss species were found, in relation to the increases of content of two metals, namely $\mathrm{Ni}$ in $P$. schreberi and $\mathrm{Pb}$ in S. palustre.

\section{Discussion}

Nowadays, not only in Poland, but also worldwide, mosses are increasingly used in biomonitoring of the ambient air pollution with heavy metals (Grodzińska 1978, Grodzińska and Szarek 1995; Berg and Steinnes; 1997 Grodzińska in. 1999; Dmuchowski and Bytnerowicz 2009; Chen et al. 2010; Malzahn and Wójcik 2012; Baczewska et al. 2016; Hu et al. 2018). That is due to the fact that most of the elements, accumulated by mosses, come precisely from the air, so they reflect well the actual pollution.

The significant differences we found in the moss metal content between the monitored sites, indicated a clear spatial variation in the contaminant deposition in Warsaw in 2020. Both moss species, Sphagnum palustre and Pleurozium schreberi, accumulated substantially higher concentrations of metals at the two sites - UKSW and DK7, compared to the remaining sites. Moreover, at site 1 and/or 2, S. palustre accumulated significantly more $\mathrm{Cd}, \mathrm{Cr}, \mathrm{Cu} \mathrm{Fe}, \mathrm{Pb}$ than P. schreberi. Thus, it seems that the results provide only partial support for our fourth working hypothesis. Some differences in the metal accumulation capacity of different moss species, even among those collected from the same biotope, were found by Chen et al. (2010). The authors pointed out that biological traits, such as living form, morpha, 
Table 2. Increments (RAFs values) of heavy metal concentrations in Sphagnum palustre after 4 months of exposure. See Fig. 1 and Table 1 for site names and locations. The highest two increments for each metal are given in bold

\begin{tabular}{cccccccc}
\hline Site & $\mathrm{Cd}$ & $\mathrm{Cr}$ & $\mathrm{Cu}$ & $\mathrm{Fe}$ & $\mathrm{Ni}$ & $\mathrm{Pb}$ & $\mathrm{Zn}$ \\
\hline 1 & $\mathbf{9 . 7 6}$ & $\mathbf{2 4 . 0 4}$ & 4.51 & $\mathbf{5 . 4 9}$ & $\mathbf{9 . 9 8}$ & $\mathbf{1 1 . 4 0}$ & $\mathbf{4 . 6 6}$ \\
\hline 2 & 8.55 & $\mathbf{1 7 . 7 3}$ & $\mathbf{9 . 2 3}$ & $\mathbf{5 . 6 1}$ & $\mathbf{8 . 9 2}$ & $\mathbf{1 0 . 9 3}$ & $\mathbf{2 . 9 2}$ \\
\hline 3 & 8.15 & 7.70 & $\mathbf{3 . 5 1}$ & 3.05 & 6.81 & 3.70 & 1.48 \\
\hline 4 & $\mathbf{9 . 5 1}$ & 5.06 & $\mathbf{4 . 6 8}$ & 2.97 & 8.38 & 5.74 & 1.67 \\
\hline 5 & 7.78 & 1.13 & 1.24 & 0.87 & 4.34 & 1.80 & 2.27 \\
\hline 6 & 7.18 & 1.08 & 1.01 & 0.88 & 4.13 & 2.74 & 1.63 \\
\hline 7 & 8.48 & 1.08 & 0.84 & 0.82 & 3.77 & 1.92 & 0.98 \\
\hline
\end{tabular}

Table 3. Increments (RAFs values) of heavy metal concentrations in Pleurozium schreberi after 4 months of exposure. See Fig. 1 and Table 1 for site names and locations. The highest two increments for each metal are given in bold

\begin{tabular}{crrrrrrr}
\hline Site & $\mathrm{Cd}$ & $\mathrm{Cr}$ & $\mathrm{Cu}$ & $\mathrm{Fe}$ & $\mathrm{Ni}$ & $\mathrm{Pb}$ & $\mathrm{Zn}$ \\
\hline 1 & $\mathbf{7 . 6 2}$ & $\mathbf{3 1 . 9 5}$ & $\mathbf{3 . 8 3}$ & $\mathbf{3 . 5 9}$ & $\mathbf{2 3 . 7 0}$ & $\mathbf{6 . 3 4}$ & 2.57 \\
\hline 2 & 6.80 & $\mathbf{1 6 . 9 4}$ & $\mathbf{5 . 9 5}$ & $\mathbf{3 . 3 4}$ & $\mathbf{1 2 . 5 6}$ & $\mathbf{6 . 4 9}$ & $\mathbf{2 . 6 4}$ \\
\hline 3 & 6.39 & 9.45 & $\mathbf{3 . 8 6}$ & 2.16 & 10.86 & 2.72 & 1.82 \\
\hline 4 & $\mathbf{7 . 5 6}$ & 6.15 & 2.80 & 1.84 & 10.91 & 2.37 & $\mathbf{3 . 4 0}$ \\
\hline 5 & 5.54 & 2.76 & 0.58 & 0.55 & 7.09 & 1.00 & 1.69 \\
\hline 6 & 6.20 & 2.28 & 1.27 & 0.63 & 8.08 & 1.57 & 1.55 \\
\hline 7 & 6.29 & 1.65 & 0.70 & 0.39 & 6.65 & 0.86 & 1.65 \\
\hline
\end{tabular}

etc., can have a great influence on the moss species accumulation capacity. Therefore, it is reasonable to assume that the higher accumulation of metals by $S$. palustre in our study, may be due to its characteristics, such as high cation exchange capacity, specific surface area of $200 \mathrm{~m}^{2} / \mathrm{g}$, and porosity of about $95 \%$ (Traczewska 2011, 100), which probably made the moss absorb elements from the environment more easily.

At all monitored sites, the accumulation of metals in both moss species can be ranked similarly, starting from the highest concentrations: $\mathrm{Fe}>\mathrm{Zn}>\mathrm{Cu}>\mathrm{Cr}>\mathrm{Pb}>\mathrm{Ni}>\mathrm{Cd}$. A similar ranking of metal accumulation in the moss P. schreberi after a 6-month exposure, was obtained by Jóźwiak and Cieplicka $(2012,42)$ in a study on the $S_{7}$ route near the town of Kielce, as well as by Malzahn and Wójcik (2012) in the long-term biomonitoring (1994-2009) conducted in Białowieża Forest.

Based on the content of eight heavy metals ( $\mathrm{Cd}, \mathrm{Cr}, \mathrm{Cu}, \mathrm{Fe}, \mathrm{Ni}, \mathrm{Pb}, \mathrm{V}$ and $\mathrm{Zn}$ ) in the moss P. schreberi, Grodzińska and Szarek (1995, 33-35) defined 4 zones of air pollution in Poland, from the "clean" zone (north-eastern part of the country, Białowieża Forest) through the moderately polluted zone (including Warsaw agglomeration), to the heavily and very heavily polluted zone (south-eastern part of the country). In the "clean" zone, the moss contained less than $1,000 \mathrm{Fe}, 60 \mathrm{Zn},{ }_{12} \mathrm{Cu}, 25 \mathrm{~Pb}$ and 0.50 $\mathrm{Cd} \mathrm{mg/kg}$. In our study, lower concentrations of all analysed metals in both moss species were found, only before the exposition. After the exposition, the accumulated content of $\mathrm{Cd}$ and $\mathrm{Zn}$ in mosses at all monitored sites, and $\mathrm{Fe}$ and $\mathrm{Cu}$ contents in mosses at sites UKSW and DK No. 7, were higher than the above-mentioned values, while $\mathrm{Pb}$ concentrations were within the range of values reported for the "clean" zone.

Comparing our results with the average metal contents: $550 \mathrm{Fe}, 61.6 \mathrm{Zn}, 1.18 \mathrm{Cr}, 10.7$ $\mathrm{Cu}, 1.62 \mathrm{Ni}, 13.9 \mathrm{~Pb}, 0.68 \mathrm{Cd} \mathrm{mg} / \mathrm{kg}$ found in the P. schreberi in Poland in 2000 (Suchara 
et al. 2007, 43-45), it can be seen that in our study, the mean content of $\mathrm{Cd}, \mathrm{Ni}$ and $\mathrm{Zn}$ in the mosses at all sites in Warsaw, the content of $\mathrm{Cr}, \mathrm{Cu}$, and $\mathrm{Fe}$ at the sites 1-4 (UKSW, DK no. 7, IMGW, Centrum), and the Pb content at the sites 1 and 2, far exceeds the concentrations of these metals in mosses from 2000.

The concentrations of $\mathrm{Cd}, \mathrm{Pb}$, and $\mathrm{Zn}$ in mosses from our study, can also be compared with the results of Dmuchowski and Bytnerowicz (2009, 3416), on the moss metal content for the city of Warsaw in 2004 - 0.35 $\mathrm{Cd}, 7.9 \mathrm{~Pb}$ and $53 \mathrm{Zn} \mathrm{mg} / \mathrm{kg}$. It turned out that the mosses currently accumulated less $\mathrm{Pb}$ (except the site 1 and 2), but much more $\mathrm{Cd}$ and $\mathrm{Zn}$ than 15 years ago.

On the basis of the concentrations of metals in mosses, the monitored sites in our study can be assigned to 3 zones, with different levels of air pollution with heavy metals. The most polluted areas include the sites of UKSW and DK no. 7, intermediate - IMGW and Centrum, and the least polluted - Siekierki, Ząbki, and Wawer. The UKSW and DK no. 7 sites are located close to the ArcelorMittal smelter (one of the main emitters of air pollution in Warsaw, according to Dmuchowski et al. 2001, Baczewska et al. 2016) and very close to heavy traffic on the Warsaw-Gdańsk route. In addition, with a high probability, the ongoing construction of the Faculty of Medicine at the time of the moss exposure, and as well as the operating gas station at site 2, would have influenced the metal accumulation by mosses on these sites.

Baczewska et al. (2016) using the moss species Sphagnum fallax, conducted a biomonitoring study in Warsaw. The heavy metal contents they found in the mosses near a steel mill were as follows: $\mathrm{Cd}-0.77$; $\mathrm{Cr}-2.03 ; \mathrm{Pb}-9.29 ; \mathrm{Zn}-118.3 \mathrm{mg} / \mathrm{kg}$. Both moss species from our study, accumulated the same metals in higher amounts. For example, at the UKSW site in the moss $S$. palustre, we found the following contents: $\mathrm{Cd}-1.18 ; \mathrm{Cr}-20.04 ; \mathrm{Pb}-16.20 ; \mathrm{Zn}-$ $436.48 \mathrm{mg} / \mathrm{kg}$. The discrepancy in the results could be explained by increased emissions from the smelter, or by additional contamination, related to the construction activities on the UKSW campus. Another factor which should be taken into consideration is the different term of the moss exposure in the two studies: June-September in Baczewska et al. (2016), and August-November in this study. As our results have shown, there were distinct differences in the levels of accumulation of the analysed metals in mosses, between the two exposure periods: August-September and October-November. The seasonal changes we found in the content of metals in mosses, can be related to changes of their concentration in the air during the calendar year. Thus, the relatively close proximity of single-family housing to the UKSW and DK7 sites, and the beginning of the heating season during the 2nd exposure period (October-November), may be a factor which influences the rate of heavy metal accumulation by the mosses. Some differences in the level of metal accumulation in mosses, depending on the exposure term, were also observed by $\mathrm{Hu}$ et al. (2018).

Significantly lower contents of heavy metals in mosses at sites "Siekierki", "Ząbki", and "Wawer", than at the other sites, indicate that these areas are less contaminated. It should be emphasised that these three sites were located in the area of Family Allotment Gardens, surrounded by a large number of trees and shrubs. In spite of the closer proximity of the Siekierki CHP plant to the "Siekierki" and "Wawer" sites, there was no significant accumulation of metals in the mosses, which means that the CHP plant was not a significant source of air pollution during the study period.

Our results showed that, despite the high absolute accumulation of $\mathrm{Fe}, \mathrm{Zn}$, and $\mathrm{Cu}$ in mosses at all sites, based on the relative accumulation factors (RAF values), the highest increments during the exposure period were found for $\mathrm{Cr}>\mathrm{Pb} \geq \mathrm{Ni}$ at sites 1 and 2, and for $\mathrm{Cd}$ and $\mathrm{Ni}$ at sites 3-7. This shows that 
the contribution of particular metals to air pollution, varies between Warsaw districts.

\section{Conclusion}

The analysis of the heavy metal contents in the mosses Pleurozium schreberi and Sphagnum palustre, exposed at various distances from potential sources of pollution (roads and freeways, railways, combined heat and power plants, smelter, petrol stations, construction works, etc.) allowed us to assess the degree of air pollution in Warsaw in 2020. The higher concentrations of some heavy metals in the mosses, compared to previous assessments, indicate a negative influence of the ongoing urbanisation (rapid growth of industries, urban infrastructure, and economic development) on the air pollution in the city.

Our study confirmed the indicator value of mosses, which means that biological monitoring using mosses, can be a valuable complement to State Environmental Monitoring for air pollution.

Author Contributions: Conceptualisation, K.I-M. and P.P.; Methodology, K.I-M., P.P. and M.S.; Investigation, P.P. and K.I-M.; Visualization, P.P.; Writing - Original Draft Preparation, K.I-M. and P.P.; Writing - Review \& Editing, K.I-M.; Supervision, K.I-M. All authors have read and agreed to the published version of the manuscript.

Funding: This research received no external funding. Institutional Review Board Statement: The study was approved by the Minister of Climate and Environment of Poland - decision nr. DOP-WPN.436.107.2020.MŚ, dated June 18, 2020.

Conflicts of Interest: The authors declare no conflict of interest.

Acknowledgements: The authors would like to thank Director of the Kampinos National Park for agreeing to collect plant material for research, Director of the Centre for Hydrological-Meteorological Measurement and Observation Network of the Institute of Meteorology and Water Management the National Research Institute, for the possibility of exhibiting samples on the premises of the Institute, Ms. Dorota Kamińska, Prof. Grzegorz Makulec, Mr. kukasz Kobier, as well as the Administration of the building at 23 Bracka St. in Warsaw, for the possibility of exposition of the moss samples on their premises.

\section{References}

Baczewska, Aneta H., Wojciech Dmuchowski, Barbara Gworek, Piotr Dąbrowski, and Paulina Brągoszewska. 2016. "Porównanie metod bioindykacyjnych $\mathrm{w}$ ocenie stopnia zanieczyszczenia środowiska metalami ciężkimi w Warszawie." [Comparison of bioindicaton methods for assessing the level of air pollution with heavy metals in Warsaw]. Przemyst Chemiczny 95(3): 334-338. doi.10.15199/62.2016.3.1

Berg Torunn, and Eiliv Steinnes. 1997. "Use of mosses Hylocomium splendens and Pleurozium schreberi as biomonitors of heavy metal deposition: from relative to absolute deposition values." Environmental Pollution 98: 61-71.

Chen, Y.E., Shenfang Yuan, Y.Q. Su, and Lei Wang. 2010. "Comparison of heavy metal accumulation capacity of some indigenous mosses in Southwest China cities: a case study in Chengdu city." Plant Soil and Environment 56: 60-66.

Chmielewski, Waldemar, Wojciech Dmuchowski and Barbara Gworek. 1993. „Wykorzystanie metody moss-bag w lokalnym biomonitoringu zanieczyszczenia powietrza metalami ciężkimi." [Use of the moss-bag method in local biomonitoring of heavy metal air pollution]. Pradnik. Prace i Materiaty Muzeum im. Prof. Wt. Szafera (7-8): 181-185.

Dmuchowski, Wojciech, Marta Badurek, and Waldemar Chmielewski. 2001. "Ocena zanieczyszczenia powietrza metalami ciężkimi $(\mathrm{Pb}, \mathrm{Cr}) \mathrm{w}$ Warszawie w latach 1992-2000 metodą "moss-bag"." [Atmospheric air pollution with heavy metals (Pb, Cr) in Warsaw in 1992-2000, measured by the "moss-bag" method]. Zeszyty Problemowe Postępów Nauk Rolniczych 476: 99-105.

Dmuchowski, Wojciech, and Andrzej Bytnerowicz, 2009. "Long-term (1992-2004) record of lead, cadmium, and zinc air contamination in Warsaw, Poland: Determination by chemical analysis of moss bags and leaves of Crimean linden." Environmental Pollution 157: 3413-342.

Feder, William A., William J. Manning, 1978, "Living plants as indicators and monitors." In Handbook of Methodology for the Assessment of Air Pollution Effects on Vegetation, edited by Walter W. Heck, Sagar V. Krupa, and S.N. Linzon, 91-94. Pittsburgh: TE-2 Agricultural Committee, Air Pollution Control Association, PA. 
GIOŚ 2020 - Roczna ocena jakości powietrza w województwie mazowieckim. Raport wojewódzki za rok 2019, Warszawa: Główny Inspektorat Ochrony Środowiska. [Annual assessment of air quality in the Mazowieckie Voivodeship. The voivodeship report for the year 2019, Warsaw: Chief Inspectorate of Environmental Protection]. GIOŚ 2021 - Roczna ocena jakości powietrza w województwie mazowieckim. Raport wojewódzki za rok 2020. Warszawa: Główny Inspektorat Ochrony Środowiska. [Annual assessment of air quality in the Mazowieckie Voivodeship. The voivodeship report for the year 2020, Warsaw: Chief Inspectorate of Environmental Protection]. Goodman, Gordon T., and Taylor M. Roberts. 1971. "Plants and soil as indicators of metals in the air." Nature 231: 287-292.

Grodzińska, Krystyna. 1978. “Mosses as bioindicators of heavy metal pollution in Polish national parks." Water, Air, and Soil Pollution 9 (1): 83-97.

Grodzińska, Krystyna, and Grażyna Szarek. 1995. "Skażenie środowiska Polski na tle Europy." [Environmental pollution in Poland compared to Europe]. Wiadomości Botaniczne 39: 31-38.

Grodzińska, Krystyna, Grażyna Szarek-Łukaszewska, and Barbara Godzik. 1999. "Survey of heavy metal deposition in Poland using mosses as indicators". Science of The Total Environment 229 (1-2): 41-51.

Hu, R., Y. Yan, X. Zhou, Y. Wang, and Y. Fang. 2018. "Monitoring heavy metal contents with Sphagnum junghuhnianum moss bags in relation to traffic volume in Wuxi, China." International Journal of Environmental Research and Public Health $15,374$.

Jóźwiak, Małgorzata A., and Kinga Cieplicka. 2012. "Zmiany makroskopowe w organach wegetatywnych mchu Pleurozium schreberi (Bird.) Mitt. pod wpływem zanieczyszczeń komunikacyjnych." [Macro-scopic changes in vegetative organs of mosses Pleurozium schreberi (Brid.) Mitt. under the influence of traffic pollution]. Rocznik Świętokrzyski. Seria B - Nauki Przyrodnicze. Kieleckie Towarzystwo Naukowe 33: 33-46.

Kłos, Andrzej. 2017. Mchy w biomonitoringu środowiska. [Mosses in environmental biomonitoring]. Warszawa: Wydawnictwo Naukowe PWN.
Kostrz, Małgorzata, and Paweł Satora. 2017. "Związki odpowiedzialne za zanieczyszczenie powietrza.” [The compounds responsible for air pollution]. Ecological Engineering, 18(6): 89-95 DOI: 10.12912/23920629/79820.

Malzahn, Elżbieta, and Józef Wójcik. 2012. “Metody stosowane w bioindykacji środowiska leśnego Puszczy Białowieskiej" [Methods used in the bioindication of the forest environment in the Białowieża Primeval Forest]. Acta Agrophysica 19(2): 355-364.

Rajfur, Małgorzata, Andrzej Kłos, Dorota Gawlik, Ludmila Hysplerova, and Maria Wacławek. 2010. "Akumulacja metali ciężkich w mchach Pleurozium schreberi eksponowanych w pobliżu toru wyścigów samochodowych w Kamieniu Śląskim." [Accumulation of heavy metals in the mosses Pleurozium schreberi, exposed near the racing track in Kamien Śląski] Proceedings of ECOpole 4(2): 477-482.

Roberts, Taylor M. 1972. "Plants as monitors of airborne metal pollution." Journal of Environmental Planning and Pollution Control, 1: 92-97

Rozbicka, Katarzyna, and Marta Michalak. 2015. “Charakterystyka stężeń wybranych zanieczyszczeń powietrza na obszarze Warszawy (Polska)." [Characteristic of selected air pollutants concentration in Warsaw (Poland)]. Scientific Review - Engineering and Environmental Sciences 68: 193-206.

Suchara, Ivan, Matej Florek, Barbara Godzik, Blanka Mankovska, Gyula Rabnecz, Julie Sucharova, Zoltàn Tuba, and Paweł Kapusta. 2007. Mapping of main sources of pollutants and their transport in the Visegrad Space. Part I: Eight toxic metals. Export group on biomonitoring the atmospheric deposition loads in the Visegrad countries. Průhonice, Výzkumný ústav Silva Taroucy pro krajinu a okrasné zahradnictví, v. v. i. Zvolen: KLEMO.

Tavares, Helena M.C.F., and M. Teresa S.D. Vasconcelos. 1996. "Comparison of lead levels collected by Sphagnum auriculatum and by a lowvolume aerosol sampler in the urban atmosphere of Oporto." Toxicological Environmental Chemistry 54:195-209. doi.org/10.1080/02772249609358312 Traczewska, Teodora M. 2011. Biologiczne metody oceny skażenia środowiska. [Biological methods 
for assessing environmental pollution]. Wrocław: Oficyna Wydawnicza Politechniki Wrocławskiej. Wójciak, Hanna. 2007. Flora Polski. Porosty, mszaki, paprotniki. [Lichens, bryophytes, ferns]. Warszawa: oficyna wydawnicza MULTICO.

Zechmeister, Harald G., Krystyna Grodzińska, and Grażyna Szarek-Łukaszewska. 2003. "Bryophytes" In Bioindicators and biomonitors, edited by Bernd A. Markert, Anton M. Breure, and Harald
G. Zechmeister, 329-375. Amsterdam: Elsevier Science B.V.

Zimny, Henry. 2006. Ekologiczna ocena stanu środowiska. Bioindykacja i biomonitoring [Ecological environmental assessment. Bioindication and biomonitoring] Warszawa: Agencja Reklamowo-Wydawnicza Arkadiusz Grzegorczyk. 